\title{
RESPIRASI TANAH PADA SEBAGIAN LOKASI DI HUTAN TAMAN NASIONAL BUKIT BARISAN SELATAN (TNBBS)
}

\author{
Natasya Anindya Putri Nasution, Sri Yusnaini, Ainin Niswati \& Dermiyati \\ Jurusan Agroteknologi Fakultas Pertanian Universitas Lampung \\ J1. Prof. Sumantri Brojonegoro No.1 Bandar Lampung 35145 \\ Email : natasya.anindyaputri@gmail.com
}

\begin{abstract}
ABSTRAK
Taman Nasional Bukit Barisan Selatan merupakan perwakilan dari rangkaian pegunungan Bukit Barisan yang terdiri dari tipe vegetasi hutan mangrove, hutan pantai, hutan tropika sampai pegunungan di Sumatera. Respirasi tanah merupakan salah satu indikator dari aktivitas biologi seperti mikroba, akar atau kehidupan lain di dalam tanah, dan aktivitas ini sangat penting untuk ekosistem di dalam tanah. Penelitian ini bertujuan untuk mempelajari respirasi tanah di beberapa lokasi di Taman Nasional Bukit Barisan Selatan (TNBBS). Penelitian ini dilakukan menggunakan metode survei, yaitu dengan pengumpulan data langsung dari beberapa lokasi di hutan TNBBS yaitu di 3 lokasi, Bukit Camp Rhino, Bukit Kilometer 26, dan Pemerihan Kecil. Uji korelasi dilakukan antara respirasi tanah dengan $\mathrm{pH}$ tanah, C-organik tanah (\%), C-organik seresah (\%), N-total tanah (\%), N-total seresah (\%), kadar air tanah (\%), kadar air seresah $(\%)$, suhu tanah $\left({ }^{\circ} \mathrm{C}\right)$, biomassa seresah, $\mathrm{C} / \mathrm{N}$ ratio tanah, dan $\mathrm{C} / \mathrm{N}$ ratio seresah. Hasil penelitian menunjukkan masing - masing lokasi memiliki respirasi tanah yang berbeda serta $\mathrm{C}$ organik tanah berkorelasi positif nyata dengan respirasi tanah dan tidak berkorelasi dengan faktor-faktor pendukung lainnya.
\end{abstract}

Kata kunci : Hutan, Respirasi, Taman Nasional Bukit Barisan Selatan (TNBBS).

\section{PENDAHULUAN}

Hutan, adalah suatu kesatuan ekosistem berupa hamparan lahan berisi sumber daya alam hayati yang didominasi pepohonan dalam persekutuan alam lingkungannya, yang satu dengan lainnya tidak dapat dipisahkan. Berdasarkan perkembangan pengukuhan kawasan hutan sampai dengan November 2012, luas kawasan hutan dan perairan seluruh Indonesia adalah mencapai 134.290.240,94 Ha (Departemen Kehutanan, 2012). Ekosistem hutan menyimpan keanekaragaman hayati yang tinggi, terutama keanekaragaman flora dan fauna. Taman Nasional Bukit Barisan Selatan (TNBBS) merupakan salah satu cagar alam di Indonesia yang memiliki keanekaragaman hayati yang tinggi.

Respirasi tanah merupakan salah satu indikator dari aktivitas biologi tanah seperti mikroba, akar tanaman atau kehidupan lain di dalam tanah, dan aktivitas ini sangat penting untuk ekosistem di dalam tanah. Penetapan respirasi tanah berdasarkan penetapan jumlah $\mathrm{CO}_{2}$ yang dihasilkan oleh mikroorganisme tanah dan jumlah $\mathrm{O}_{2}$ yang digunakan oleh mikroorganisme tanah (Anas, 1989). Menurut Hanafiah (2005), bahan organik tanah berasal dari tanaman yang tumbuh di atasnya, sehingga kadar bahan organik tanah sangat tinggi pada lapisan atas tanah dan menurun dengan bertambahnya kedalaman tanah. Tanah yang bervegetasi akan mempunyai kadar bahan organik yang tinggi, sebaliknya pada tanah yang gundul tanpa vegetasi maka kadar bahan organiknya rendah. Bahan organik memiliki peran penting dalam menentukan kemampuan tanah untuk mendukung tanaman. Oleh karena itu, jika bahan organik tanah (BOT) menurun, kemampuan tanah dalam mendukung produktivitas tanaman juga menurun. Menurunnya kadar bahan organik tanah merupakan salah satu bentuk kerusakan tanah yang umum terjadi. Tinggi rendahnya bahan organik juga mempengaruhi jumlah dan aktivitas metabolik organisme tanah. Meningkatnya kegiatan organisme tanah tersebut akan mempercepat dekomposisi bahan organik (Nurmegawati, dkk., 2014).

Di hutan TNBBS, masih banyak ditemukan kasus perambahan hutan yang menjadikan lokasi hutan beralih fungsi menjadi lahan permukiman dan juga perkebunan bagi perambah. Salah satunya adalah di daerah Pemerihan Kecil, yang dari waktu ke waktu daerah pemukiman dan perkebunan warga menjadi semakin luas di daerah tersebut. Perambahan hutan tersebut juga berdampak terhadap keadaan hutan, terutama vegetasi yang menutupinya. Perbedaan jenis lokasi, topografi 
dan iklim sangat mempengaruhi keanekaragaman flora dan fauna di TNBBS, hal ini juga dapat mempengaruhi organisme yang ada di dalam tanah yang dapat berpengaruh juga terhadap respirasi tanah. Penelitian ini bertujuan untuk mempelajari respirasi tanah di beberapa lokasi di Taman Nasional Bukit Barisan Selatan (TNBBS).

\section{BAHAN DAN METODE}

Penelitian ini dilaksanakan di Taman Nasional Bukit Barisan dari bulan Februari 2013 hingga Maret 2013. Analisis tanah dilakukan di Laboratorium Ilmu Tanah, Fakultas Pertanian, Universitas Lampung. Pengambilan sampel dilakukan pada beberapa lokasi hutan di Taman Nasional Bukit Barisan Selatan. Secara geografis terletak antara $4^{\circ} 33^{\prime}-5^{\circ} 57^{\prime} \mathrm{LS}, 103^{\circ} 23^{\prime}-104^{\circ}$ 43' BT. Terdiri dari tiga lokasi, yaitu Bukit Camp Rhino (5'30' $\left.10,68^{\prime \prime} \mathrm{S}-104^{\circ} 25^{\prime} 45,62^{\prime \prime} \mathrm{E}\right)$ dengan ketinggian $600 \mathrm{~m}$ dpl terletak di km 50 Taman Nasional Bukit Barisan Selatan (TNBBS), Bukit Kilometer 26 (531' $\left.41,60^{\prime \prime} \mathrm{S}-104^{\circ} 25^{\prime} 46,81^{\prime \prime} \mathrm{E}\right)$ dengan ketinggian $569 \mathrm{~m}$ dpl, dan Bukit Pemerihan Kecil (5³6'27,97' S 104'24'16,21" E) dengan ketinggian $113 \mathrm{~m}$ dpl . Dari masing-masing hutan, sampel yang diambil meliputi 3 tempat yaitu bagian atas, bagian tengah, dan bagian bawah serta dari tiap bagian diambil 4 sampel. Adapun jenis vegetasi pada masing-masing lokasi terlampir pada Tabel 1.

Alat yang digunakan dalam penelitian ini adalah toples plastik dengan diameter $14 \mathrm{~cm}$, plastik, spidol, label, botol film, gelas erlenmeyer, gelas ukur, biuret, alat tulis, termometer tanah serta alat-alat laboratorium lainnya untuk analisis respirasi tanah dan analisis contoh tanah. Bahan yang digunakan dalam penelitian ini adalah , Fenolptalin, metil orange, $\mathrm{KOH} 0,1 N, \mathrm{HCl} 0,1 N$, dan bahan-bahan kimia untuk analisis variabel pendukung seperti C-organik tanah (metode Walkley \& Black), pH tanah (metode elektrometrik), kelembaban tanah, Suhu tanah, dan N-total tanah (metode Kjeldahl).

Metode yang digunakan adalah metode survei, yaitu dengan mengetahui kondisi penelitian dan pengumpulan data langsung dari lapangan. Lokasi yang ada di survei, terdiri dari tiga hutan dengan tempat pengambilan sampel yang berbeda antar ketinggiannya. Setiap sampel diambil menurut topografinya baik atas, tengah maupun bawah. Sehingga lokasi pengambilan sampel terdiri dari Camp Rhino Atas (CRA), Camp Rhino Tengah (CRT), Camp Rhino Bawah (CRB), Kilometer 26 Atas (KMA), Kilometer 26 Tengah (KMT), Kilometer 26 Bawah (KMB), dan Pemerihan (P). Pengumpulan data yang diambil berupa data respirasi, penutupan lahan atau vegetasi, dan data-data pendukung lainnya yang akan dikorelasikan seperti COrganik, N-total, suhu, kelembaban, $\mathrm{pH}$ dan juga bobot seresah.

Pada pelaksanaan penelitian, lokasi hutan yang disurvey ditetapkan beberapa titik pengambilan sampel sesuai dengan topografinya, yaitu atas, tengah maupun bawah. Untuk masing-masing topografi dipilih titik yang tidak terlalu miring. Pada pengambilan sampel seresah, setiap titik pengambilan sampel, diambil seresah dengan luasan $50 \mathrm{~cm}$ x $50 \mathrm{~cm}$, yang diukur dengan menggunakan monolit yang telah dibuat sebelumnya. Seresah yang diambil, berupa semua benda yang ada di atas tanah sesuai dengan ukuran bingkai kayu. Kemudian seresah segar tersebut dimasukkan ke dalam kantung yang telah disiapkan dan diberi label. Pada pengambilan sampel tanah, tanah yang berada di bawah seresah dalam petakan monolit, diambil menggunakan cangkul dengan kedalaman 0-10 cm. Kemudian dimasukkan kedalam kantung yang telah disiapkan

Pengamatan yang dilakukan adalah Respirasi Tanah dengan Metode Modifikasi Verstraete (Anas, 1986), dan variabel pendukung yang diamati adalah kadar C-organik tanah (\%) dan C-organik seresah (\%) dengan metode Walkley dan Black, N-total tanah (\%) dan N-total seresah (\%) dengan metode Kjeldahl, $\mathrm{pH}$ tanah dengan metode elektrometrik, Kadar Air Tanah $(\%)$, Kadar Air Seresah (\%), Suhu tanah $\left({ }^{\circ} \mathrm{C}\right)$, dan biomassa seresah $(\mathrm{g})$.

Pengukuran respirasi tanah langsung dilakukan dengan mengambil sampel tanah di lapangan. Pengambilan sampel dilakukan pada pagi hingga sore hari. Setelah dilakukan pengambilan sampel di lapangan, sampel tanah dibawa ke laboratorium untuk dilakukan pengukuran respirasi. Pengukuran respirasi tanah dilakukan dengan metode modifikasi Verstraete dengan cara menimbang tanah seberat $100 \mathrm{~g}$ per sampel dan dimasukkan ke dalam wadah toples yang di dalamnya telah diberikan botol film yang berisi $10 \mathrm{ml} \mathrm{KOH} 0,1 \mathrm{~N}$ dan $10 \mathrm{ml}$ akuades. Kemudian toples ditutup sampai kedap udara dengan menggunakan selotip atau lakban, lalu di inkubasi selama satu minggu di dalam tempat yang gelap dan pada temperatur suhu kamar.

Setelah masa inkubasi selesai, $\mathrm{KOH}$ hasil pengukuran dititrasi di laboratorium untuk menentukan kuantitas $\mathrm{CO}_{2}$ yang dihasilkan. Titrasi dilakukan dengan cara memindahkan $\mathrm{KOH}$ hasil pengukuran ke dalam gelas erlenmeyer dan ditambahkan 2 tetes fenolptalin, sehingga warna berubah menjadi merah muda dan kemudian dititrasi dengan $\mathrm{HCl}$ sampai warna merah muda hilang (larutan berwarna bening), volume $\mathrm{HCl}$ yang diperlukan dicatat. Kemudian ke dalam larutan 
Tabel 1. Dominasi tegakan pada arel penelitian

\begin{tabular}{|c|c|c|}
\hline Lokasi & Titik sampel & Dominasi tegakan \\
\hline \multirow[t]{3}{*}{ Camp Rhino } & Atas (CRA) & $\begin{array}{l}\text { Tepus (Hornstedtia sp.) } \\
\text { Bambu hutan (Bambusa sp.) } \\
\text { Bandotan (Heliatropium indicum) } \\
\text { Jelatung (Dyera costulata) }\end{array}$ \\
\hline & Tengah (CRT) & $\begin{array}{l}\text { Ketapang (Terminalia cattapa) } \\
\text { Kerempil } \\
\text { Simpur (Dillenia } \text { sp.) }\end{array}$ \\
\hline & Bawah (CRB) & $\begin{array}{l}\text { Ketapang (Terminalia cattapa) } \\
\text { Meranti (Shorea sp.) } \\
\text { Bandotan (Heliatropium indicum) }\end{array}$ \\
\hline \multirow[t]{3}{*}{ Bukit Kilometer 26} & Atas (KMA) & $\begin{array}{l}\text { Duren hutan (Durio zibethinus) } \\
\text { Bandotan (Heliatropium indicum) } \\
\text { Daun cengkeh (Syzygium aromaticum) } \\
\text { Keruing (Dipterocarpus elongatus) }\end{array}$ \\
\hline & Tengah (KMT) & $\begin{array}{l}\text { Simpur (Dillenia } \mathrm{sp} .) \\
\text { Angrung (Trema orientalis L.) }\end{array}$ \\
\hline & Bawah (KMB) & $\begin{array}{l}\text { Kulut (Aglaia argentea } \text { BI.) } \\
\text { Kongki (Caesalpinia digyna) } \\
\text { Bernung (Octomelus sumatrana) }\end{array}$ \\
\hline Pemerihan Kecil & & $\begin{array}{l}\text { Rotan (Calamus sp.) } \\
\text { Gelam (Melaleuca sp.) } \\
\text { Jengkol (Pitchelobium jiringa) } \\
\text { Dammar (Shorea javanica) } \\
\text { Dammar asam (Porinari sp.) }\end{array}$ \\
\hline
\end{tabular}

Sumber : Komunikasi Pribadi dengan Philipus (2013).

ditambahkan 2 tetes metil orange sehingga larutan berwarna kuning, dan larutan dititrasi kembali dengan $\mathrm{HCl}$ hingga warna kuning berubah menjadi warna merah muda. $\mathrm{HCl}$ yang digunakan berhubungan langsung dengan jumlah $\mathrm{CO}_{2}$ yang difiksasi. Pada kontrol juga dilakukan hal yang sama. Jumlah $\mathrm{CO}_{2}$ dihitung dengan mengunakan formula:

$$
\mathrm{r}=\frac{(\mathrm{a}-\mathrm{b}) \times \mathrm{t} \times 120}{\mathrm{n}}
$$

Keterangan:

$\mathrm{a}=\mathrm{ml} \mathrm{HCl}$ untuk sampel tanah

$\mathrm{b}=\mathrm{ml} \mathrm{HCl} \mathrm{untuk} \mathrm{kontrol}$

$\mathrm{t}=$ normalitas $\mathrm{HCl}$

$\mathrm{n}=$ jumlah hari inkubasi

$\mathrm{r}=$ jumlah $\mathrm{C}-\mathrm{CO}_{2}$ yang dihasilkan tiap gram tanah lembab per hari

\section{HASIL DAN PEMBAHASAN}

Hasil pengamatan respirasi tanah pada masingmasing lokasi pada Taman Nasional Bukit Barisan Selatan (TNBBS) dapat dilihat pada Tabel 2 terlampir. Hasil survey menunjukkan bahwa hasil respirasi tanah tertinggi terdapat di lokasi Pemerihan dan respirasi tanah terendah terdapat di lokasi Bukit Kilometer 26 (KM 26).

Pada Tabel 2, dapat dilihat bahwa di tiga lokasi Camp Rhino, Kilometer 26, menunjukan hasil respirasi tanah yang berbeda pada setiap ketinggian lereng. Respirasi tanah di lokasi Camp Rhino yang paling tertinggi terdapat di lereng bagian tengah dan respirasi tanah yang terendah terdapat di lereng bagian atas. Sedangkan pada lokasi Bukit Kilometer 26, respirasi tanah tertinggi terdapat di lereng bagian bawah dan respirasi terendah terdapat di lereng bagian tengah. Hal 
Tabel 2. Respirasi tanah (mg C-CO $\mathrm{g}^{-1}$ hari ${ }^{-1}$ ) pada sebagian lokasi di Taman Nasional Bukit Barisan Selatan (TNBBS).

\begin{tabular}{lc}
\hline \multicolumn{1}{c}{ Lokasi } & $\begin{array}{c}\text { Respirasi Tanah } \\
\left(\mathrm{mg} \mathrm{C}^{-} \mathrm{CO}_{2} \mathrm{~g}^{-1} \text { hari }^{-1}\right)\end{array}$ \\
\hline Camp Rhino Atas (CRA), $675 \mathrm{~m} \mathrm{dpl}$ & $12,48 \pm 0,65$ \\
Camp Rhino Tengah (CRT), $653 \mathrm{~m} \mathrm{dpl}$ & $13,63 \pm 1,67$ \\
Camp Rhino Bawah (CRB), $615 \mathrm{~m} \mathrm{dpl}$ & $13,05 \pm 1,38$ \\
Kilometer 26 Atas (KMA), $570 \mathrm{~m} \mathrm{dpl}$ & $6,47 \pm 0,51$ \\
Kilometer 26 Tengah (KMT), $539 \mathrm{~m} \mathrm{dpl}$ & $5,66 \pm 0,34$ \\
Kilometer 26 Bawah (KMB), $486 \mathrm{~m}$ dpl & $6,56 \pm 1,05$ \\
Pemerihan (P), 120 m dpl & $16,63 \pm 0,72$ \\
\hline
\end{tabular}

Keterangan: $\mathrm{CRA}=$ Camp Rhino Atas, $\mathrm{CRT}=\mathrm{Camp}$ Rhino Tengah, $\mathrm{CRB}=$ Camp Rhino Bawah, $\mathrm{KMA}=$ Kilometer 26 Atas, $\mathrm{KMT}=$ Kilometer 26 Tengah, $\mathrm{KMB}=$ Kilometer 26 Bawah, $\mathrm{P}=$ Pemerihan

ini membuktikan bahwa ketinggian lereng tidak mempengaruhi tinggi rendahnya respirasi tanah.

Hasil analisis beberapa sifat fisik dan kimia tanah serta seresah dapat dilihat pada Tabel 3. Biomassa seresah dan $\mathrm{C} / \mathrm{N}$ ratio tanah sangat bervariasi antara lokasi satu dengan lokasi lainnya. Sedangkan hasil analisis sifat fisik dan kimia yang lain tidak jauh berbeda antara lokasi satu dengan yang lain. Lokasi Kilometer 26 bagian bawah dan Pemerihan suhu tanahnya di atas $25^{\circ} \mathrm{C}$, semakin tinggi suhu maka dapat mempengaruhi kenaikan respirasi tanah.

Berdasarkan uji korelasi pada Tabel 4, C-organik tanah berkolerasi positif nyata dengan respirasi tanah di TNBBS. Sedangkan C-organik seresah, N - Total seresah, N-total tanah, $\mathrm{pH}$ tanah, suhu tanah, kadar air seresah, kadar air tanah, $\mathrm{C} / \mathrm{N}$ ratio tanah, $\mathrm{C} / \mathrm{N}$ ratio seresah dan biomassa seresah tidak berkorelasi nyata dengan respirasi tanah.

Perbedaan tingkat respirasi pada lokasi CRA, CRT, dan CRB dengan KMA, KMT, dan KMB dikarenakan perbedaan ketinggian lereng, perbedaan vegetasi, serta keadaan bahan organiknya. Menurut Sutedjo dan Kartasapoetra (2005), kadar bahan organik di dalam tanah pada suatu tempat berlainan dan cukup beragam, hal ini menunjukkan bahwa persentase bahan organik tidak sama pada setiap lapisan tanah walau diambil pada tempat dan jenis tanah yang sama.

Respirasi tanah tertinggi terdapat di lokasi Pemerihan dengan ketinggian lokasi $120 \mathrm{~m}$ dpl, yaitu sebesar 16,63 mg C-CO $\mathrm{g}^{-1}$ hari $^{-1}$ (Tabel 2). Respirasi tanah ini berkorelasi positif dengan kadar C-organik tanah. Kadar C-organik tanah pada lokasi Pemerihan adalah sebesar $1,95 \%$. Hal ini dikarenakan di lokasi
Pemerihan dekat dengan pemukiman desa atau perkampungan dan diduga tanah di lokasi ini merupakan tanah yang terganggu sebagai hutan lindung dan lahan disekelilingnya sudah di manfaatkan oleh petani setempat untuk budidaya ubi kayu.

Pada lokasi Pemerihan tingkat vegetasi yang tidak terlalu rapat dan juga ditemukan beberapa gajah hutan, gajah hutan yang ditemukan pada lokasi Pemerihan memberikan sumbangan bahan organik ke tanah dari kotoran gajah tersebut. Selain itu, berkurangnya vegetasi penutup tanah akibat penanaman atau panen dapat menyebabkan penetrasi sinar matahari langsung sehingga dapat meningkatkan temperatur tanah, sehingga memacu dekomposisi. Penggunaan alat pertanian juga memberi peluang untuk terjadinya percampuran seresah dengan tanah yang dapat meningkatkan bahan organik tanah dan dapat meningkatkan respirasi lebih tinggi.

Bahan organik mempunyai peranan yang penting di dalam tanah, yaitu terhadap sifat-sifat tanah (Reeves, 1997). Pemberian bahan organik dan sisa bahan organik tidak hanya berfungsi sebagai sumber hara melainkan dapat meningkatkan jumlah, keanekaragaman, mikroorganisme, serta aktvitas mikroorganisme dalam tanah (Albiach, dkk., 2000).

Penambahan pupuk hijau, sisa-sisa tanaman dan pupuk kandang berpengaruh nyata terhadap kandungan C-Organik tanah, hal ini disebabkan karena bahan organik (pupuk kandang) di dalam tanah akan diurai oleh mikroorganisme tanah yang memanfaatkannya sebagai sumber makanan dan energi menjadi humus, sehingga dengan banyaknya bahan organik yang diberikan maka akan semakin tinggi nilai C-Organik tanah (Sandrawati, 2007). 
Tabel 3. Hasil analisis beberapa sifat fisik dan kimia tanah serta seresah.

\begin{tabular}{|c|c|c|c|c|c|c|c|}
\hline \multirow{2}{*}{$\begin{array}{l}\text { Sifat Fisik dan Kimia } \\
\text { Tanah dan Seresah }\end{array}$} & \multicolumn{7}{|c|}{ Lokasi } \\
\hline & CRA & CRT & $\mathrm{CRB}$ & KMA & KMT & KMB & $\mathrm{P}$ \\
\hline \multicolumn{8}{|l|}{ Tanah } \\
\hline C-Organik tanah (\%) & 2,13 & 1,25 & 2,39 & 1,29 & 1,84 & 1,20 & 1,95 \\
\hline N-total tanah $(\%)$ & 0,76 & 0,60 & 0,54 & 0,51 & 0,49 & 0,58 & 0,71 \\
\hline $\mathrm{C} / \mathrm{N}$ ratio tanah & 2,90 & 2,31 & 4,67 & 2,57 & 4,24 & 2,11 & 2,84 \\
\hline $\mathrm{pH}$ tanah & 5,87 & 5,73 & 6,07 & 5,44 & 5,35 & 5,70 & 5,42 \\
\hline Suhu tanah $\left({ }^{\circ} \mathrm{C}\right)$ & 21,90 & 22,28 & 22,35 & 24,20 & 23,73 & 25,03 & 26,10 \\
\hline Kadar air tanah $(\%)$ & 33,03 & 35,19 & 36,60 & 34,27 & 35,86 & 36,57 & 34,52 \\
\hline \multicolumn{8}{|l|}{ Seresah } \\
\hline C-organik seresah (\%) & 20,88 & 21,54 & 20,37 & 19,64 & 18,81 & 17,90 & 18,56 \\
\hline N-total seresah $(\%)$ & 1,51 & 1,35 & 1,18 & 1,29 & 1,12 & 1,05 & 1,26 \\
\hline $\mathrm{C} / \mathrm{N}$ ratio seresah & 14,03 & 16,19 & 17,60 & 15,27 & 16,86 & 17,57 & 15,52 \\
\hline Kadar air seresah $(\%)$ & 13,03 & 15,19 & 16,60 & 14,27 & 15,86 & 16,57 & 14,52 \\
\hline Biomassa seresah $(\mathrm{g})$ & 520 & 576 & 1091 & 1101 & 611 & 265 & 410 \\
\hline
\end{tabular}

Tabel 4. Korelasi antara respirasi tanah dengan C-organik seresah, N-total seresah, pH tanah, suhu tanah, kadar air seresah dan biomassa seresah di hutan TNBBS.

\begin{tabular}{ll}
\hline \multicolumn{1}{c}{ Korelasi } & Koefisien Korelasi \\
\hline Tanah / Respirasi & \\
\hline C-Organik tanah & $0,448^{*}$ \\
N-total tanah & $0,366^{\text {tn }}$ \\
C/N ratio tanah & $0,157^{\text {tn }}$ \\
pH tanah & $0,291^{\text {tn }}$ \\
Suhu tanah & $-0,101^{\text {tn }}$ \\
Kadar air tanah & $-0,103^{\text {tn }}$ \\
\hline Seresah / Respirasi & \\
\hline C-organik seresah & $0,262^{\text {tn }}$ \\
N-total seresah & $0,341^{\text {tn }}$ \\
C/N ratio seresah & $-0,110^{\text {tn }}$ \\
Kadar air seresah & $-0,110^{\text {tn }}$ \\
Biomassa seresah & $-0,068^{\text {tn }}$ \\
\hline
\end{tabular}

Keterangan : $\mathrm{tn}=$ tidak berkorelasi nyata pada taraf $5 \%, *=$ berkorelasi nyata pada taraf $5 \%$ 
Walaupun C-organik tanah yang terdapat pada lokasi Pemerihan lebih rendah daripada lokasi Camp Rhino bagian atas (CRA) dan bagian bawah (CRB), tetapi tingkat respirasinya tinggi bila dibandingkan dengan CRA dan CRB. Hal ini dikarenakan suhu yang tinggi $\left(>26^{\circ} \mathrm{C}\right)$ pada lokasi Pemerihan. Sehingga aktivitas mikroorganisme tinggi, $\mathrm{C}$-organik tanah cepat habis dan menghasilkan respirasi tanah yang tinggi. Berbeda halnya dengan Camp Rhino, yang mempunyai kadar seresah tinggi, sehingga memiliki kadar C-organik tanah yang tinggi pula,hal ini sesuai dengan pernyataan Dermiyati (1997) menyatakan selain pupuk kandang atau kotoran hewan, seresah tanaman merupakan sumber energi bagi mikroorganisme tanah. Bahan organik tersebut dapat berfungsi sebagai sumber energi untuk mikroorganisme tanah, sehingga dapat memacu perubahan biologi tanah. Dengan demikian mikroorganisme tanah dapat ditingkatkan aktivitasnya oleh pembenaman dan penutupan permukaan tanah oleh seresah oleh sisa tanaman. Walaupun C-organik tanahnya tergolong tinggi, tetapi tingkat repirasi tanahnya rendah. Hal ini dikarenakan rendahnya suhu pada lokasi Camp Rhino berkisar $\left( \pm 22^{\circ} \mathrm{C}\right)$ yang dapat menghambat aktivitas mikroorganisme dalam melakukan respirasi tanah.

Hasil yang berbeda pada Bukit Kilometer 26, bahwa tingkat respirasi $(5,66 \sim 6,56)$, disebabkan oleh rendahnya C-organik tanah $(1,20 \sim 1,84 \%)$. Kadar Corganik yang rendah di lokasi Bukit Kilometer 26 berakibat pada rendahnya respirasi tanah pada kawasan tersebut. Pada kawasan hutan lebat, tidak menjamin terjadinya respirasi tanah yang tinggi, walaupun terdapat banyak seresah, namun dikarenakan ketebalan seresah yang tinggi dan juga ketebalan vegetasi hutan mengakibatkan sulitnya seresah untuk terdekomposisi dan membutuhkan waktu yang lama untuk terurai agar dapat menjadi sumber energi bagi mikroorganisme. Hal ini juga sejalan dengan penelitian Valentina (2013), yang menyatakan bahwa lokasi Bukit Kilometer 26 dipenuhi oleh seresah - seresah yang kaya akan serat sehingga menyebabkan lamanya proses dekomposisi yang membuat ketersediaan sumber energi dan nutrisi bagi fauna tanah terjamin lebih lama tersedia sehingga fauna tanah tidak bertahan di lokasi tersebut.

$\mathrm{C} / \mathrm{N}$ ratio tanah pada lokasi TNBBS ini tergolong rendah yang berarti bahan organik yang berada di dalam tanah sudah terdekomposisi. Hasil korelasi $\mathrm{C} / \mathrm{N}$ ratio tanah dengan respirasi tanah pada Tabel 4 menunjukkan tidak adanya korelasi antara $\mathrm{C} / \mathrm{N}$ ratio tanah dengan respirasi tanah. $\mathrm{C} / \mathrm{N}$ ratio seresah yang terdapat di lokasi penelitian ini relatif lebih tinggi daripada $\mathrm{C} / \mathrm{N}$ ratio tanah, yaitu berkisar antara 14-18. Seresah ini dapat dikategorikan berkualitas tinggi karena menurut Handayanto (1994), seresah yang berkualitas tinggi adalah seresah yang mempunyai $\mathrm{C} / \mathrm{N}$ ratio $<20$. Namun dalam penelitian ini $\mathrm{C} / \mathrm{N}$ ratio seresah tidak berpengaruh terhadap respirasi tanah. Dari hasil penelitian ini dapat dilihat bahwa suhu tanah tidak berpengaruh nyata terhadap respirasi tanah. Pada keseluruhan lokasi penelitian, memiliki suhu antara $21^{\circ} \mathrm{C}-26^{\circ} \mathrm{C}$. Umumnya proses dekomposisi maksimum pada temperatur $27^{\circ} \mathrm{C}$ $31^{\circ} \mathrm{C}$. Pada temperatur dibawah $27^{\circ} \mathrm{C}$ atau di atas $31^{\circ} \mathrm{C}$ akan terhambat. Pengambilan sampel suhu hanya dilakukan sekali ketika dilakukan pengambilan sampel, dan proses dekomposisi telah berlangsung lama sebelumnya, sehingga tidak berpengaruh.

\section{KESIMPULAN}

Dari hasil penelitian dapat disimpulkan bahwa respirasi tanah pada berbagai lokasi di TNBBS bervariasi, respirasi tanah tertinggi di lokasi Pemerihan dan terendah di lokasi Bukit Kilometer 26 lereng bagian tengah dan tinggi rendahnya respirasi pada masingmasing lokasi ditentukan oleh faktor lingkungan yang berbeda-beda.

\section{DAFTAR PUSTAKA}

Albiach, R., R. Canet, F.Pomares, dan F.Ingelmo. 2000. Microbial biomass content and enzymatic after the application of organic amendments to a horticultural. Soil. Biores. Tech. 75: 43-48.

Anas, I. 1989. Biologi Tanah Dalam Praktik. Departemen Pendidikan dan Kebudayaan Direktorat Jendarl Pendidikan Tinggi Pusat antar Universitas Bioteknologi Institut Pertanian Bogor. Bogor. $173 \mathrm{hlm}$.

Departemen Kehutanan. 2012. Data dan Informasi Pemanfaatan Hutan Tahun 2012. http:// www.dephut.go.id/files/stat2011.pdf. Diakses pada tanggal: 25 Januari 2013.

Dermiyati. 1997. Effect of Mulch Application on Soil Microorganism Activities and Yield of Corn. $J$. Trop Soil. III (5): 63-68.

Hanafiah, K. A. 2005. Dasar-Dasar Ilmu Tanah. Grafindo Prasada. Jakarta. $360 \mathrm{hlm}$.

Handayanto, E. 1994. Nitrogen Mineralization from Legume Tree Prunings of Different Quality. Thesis for Doctor of Phylosophy. Wye College, University of London. 
Nurmegawati, Afrizon, dan D.Sugandi. 2014. Kajian kesuburan tanah perkebunan karet rakyat di Provinsi Bengkulu. J. Littri Puslitbang Perkebunan. 20 (1) : 17-26.

Reeves.W. 1997. The role of soil organic matter in maintaining soil quality in continuous cropping system. Soil and Tillage Research. 43: 131-167.

Sandrawati, A. 2007. Pengaruh kompos sampah kota dan pupuk kandang ayam terhadap beberapa sifat kimia tanah dan hasil tanaman jagung manis (Zea Mays Saccharata) pada Fluventic Eutrudeps asal
Jatinangor Kabupaten Sumedang. J. Ilmu Tanah. 14: 13-14.

Soetedjo, M.M., A.G. Kartasapoetra, dan R.D.S. Sastroatmodjo. 1991. Mikrobiologi Tanah. Rineka Cipta. Jakarta. 177 hlm.

Valentina, D.A. 2013. Populasi dan keanekaragaman mesofauna tanah dan seresah di hutan Taman Nasional Bukit Barisan Selatan (TNBBS). Skripsi. Fakultas Pertanian Universitas Lampung: Bandar Lampung. $50 \mathrm{hlm}$. 